\title{
Effect of Government Infrastructure Investment on Economic Growth in Kenya
}

\author{
Elizabeth Wangai Njiru ${ }^{*} \quad$ Justo Masinde Simiyu ${ }^{2} \quad$ Aggrey Otieno Bunde ${ }^{1}$ \\ 1.Department of Social Sciences, Chuka University, P.O Box 109 -60400, Chuka, Kenya \\ 2.Department of Business, Tharaka University College, P.O Box 193-60215 Marimanti, Kenya
}

\begin{abstract}
Government investment in infrastructure is a precursor to the achievement of sustainable economic growth and poverty reduction goals of any economy. Despite shortage of capital, the Kenyan government has continuously invested in both economic infrastructure and social infrastructure with the aim of raising economic growth. However, the growth rate has stagnated at an average of 5\% annually for the last 5 years despite the projection of annual growth rate of $10 \%$ from 2012 as per Vision 2030. The main objective of this study was to determine the effect of government infrastructure investment on economic growth in Kenya for the period 1990 to 2017. The study adopted Error Correction Model for estimation and conducted the regression analysis using Ordinary Least Squares. Granger causality test found that economic infrastructure investment causes economic growth in Kenya but social infrastructure investment has neutral causality with economic growth. Further, the study found that government investment in economic infrastructure has a positive and significant effect on economic growth in Kenya with a p-value $0.0000<0.05$ while social infrastructure investment has a negative and insignificant effect on economic growth with a p-value of $0.8798>0.05$. Additionally, the study established that private investment and labour force have negative and significant effect on economic growth in Kenya. Since infrastructure spending in Kenya is still inadequate, the study recommends the government to increase funds directed to infrastructure investment in the country to the World Bank's infrastructure investment threshold of 7-9\% of GDP, as this will translate to improved productivity as a result of increased physical and human capital leading to actualization of the $10 \%$ economic growth rate. The study also recommends complementary government spending to private sector investment since the marginal capital of private capital will be increased leading to higher productivity. Finally, the government should promote conducive environment for private sector investment so that more jobs can be created that will absorb the underutilized or unemployed labour force in the country.
\end{abstract}

Keywords: Government, Infrastructure, Investment, Economic Growth, Error Correction Model

DOI: $10.7176 / \mathrm{JESD} / 11-4-09$

Publication date: February $29^{\text {th }} 2020$

\section{Introduction}

Reliable, adequate and quality infrastructure is a pre-condition for take-off into self-sustained growth (Rostow, 1960). Public infrastructure investment refers to physical capital investments traditionally provided by public sector to private households and businesses (Fox \& Smith, 1990). According to Smith (1776) infrastructure is all about the necessity of public establishments and buildings needed for social productions processes but unprofitable for private capital. This could be due to the fact that infrastructure provision and financing exhibit the characteristics of public goods of non-excludability in supply and non-rivalry in consumption. In addition, Mudida (2010) argues that free rider problem arises when public goods are provided by private sector. Thus, these issues suggest that the government has a role to play in efficiently supplying and maintaining infrastructure, especially when it spans across geographic borders. Hirschman (1958) also defined infrastructure as basic services without which primary, secondary and tertiary productive activities cannot function. However, Fox and Porca (2001) argued that it is important to differentiate between physical facilities from which infrastructure services are provided and the services themselves. Therefore, infrastructure refers to fixed physical structures of various types used by industries as inputs in the production of various goods and services and it involves strong public involvement. Public investment in infrastructure is highly regarded as a key booster of economic growth since it enhances the productivity of existing infrastructure resources while at the same time it increases the resource base of an economy by adding new infrastructure (Gakuo, 2015). Mburu (2013) points out that public infrastructure investment occurs in three ways namely; capital reinvestment in existing public infrastructure, capital investment in new public infrastructure and operation and maintenance of existing infrastructure.

Generally, infrastructure is divided into two categories namely; economic and social infrastructure. Economic infrastructure comprises investments that raise the productivity of other types of physical capital and it includes transport, energy, Information and Communication Technology (ICT) and water and sanitation. On the other hand, social infrastructure refers to investments that facilitate and enhance productivity of human capital and it includes education and health (Fedderke \& Garlick, 2008; Hansen, 1965; Kularatne, 2006; Mugambi, 2016; Perkins, 2003; Sahoo, Dash \& Nataraj, 2010; United Nations Human Settlements Programme, 2011). The two main approaches used to measure infrastructure are physical and financial measures (Fedderke \& Garlick, 2008). Financial measure 
is used commonly when examining aggregate infrastructure stocks or flows. However, according to Gramlich (1994) this measure can be used also for infrastructure data disaggregated by type. In contrast, physical measure involves taking inventory of the quantity of the pertinent structures and facilities (Kularatne, 2006) and it is used when examining specific types of infrastructure. Nevertheless, Romp and De Haan (2007) assert that this measure neither provides clarity nor correct for quality. Therefore, the existing literature is not in consensus on the effective measure of infrastructure.

Economic growth refers to sustained increase in the productive capacity of a country which raises the ability of an economy to produce additional stock of goods and services. It is measured by Gross Domestic Product, which according to World Bank (2013) is the sum of gross value added by all resident producers in the economy plus any productive taxes minus any subsidies not included in the value of the products. In the 1960s and 1970s, the Kenyan economy grew at the rate of $6-7 \%$ and the country was at par with some of the newly industrialized countries of East Asia like South Korea, Taiwan and Malaysia. However, the economic growth rate in 1980s and 90s declined and this was majorly due to stabilization policies and structural adjustment programs from World Bank and International Monetary Fund. Due to slow economic growth rates, the government implemented the Economic Recovery Strategy for Wealth and Employment Creation (ERSWEC) in 2003-2007 and as a result the GDP growth increased steadily from a low of $1 \%$ in 2002 to $7.1 \%$ in 2007 , before a drastic decline to $1.7 \%$ in 2008 majorly due to postelection violence shock. All in all, from 2008 to 2012 the economy grew at an average of $4.7 \%$. Importantly, following the rebasing of GDP in 2014, Kenya became a lower middle income country with a Gross National Income per capita of US\$1,160 (World Bank, 2016). This makes Kenya's performance to be compared with countries like Nigeria, India, Egypt and Yemen among others. Consequently, statistics indicate that the Kenyan economy grew by 5.7\%, 5.3\%, 5.6\%, 5.8\% and 4.9\% in 2013, 2014, 2015, 2016 and 2017 respectively. However, the Kenya Vision 2030 aims to transform the country to an upper-middle income country by the year 2030 while growing annually by a 10\% growth rate, though this growth rate has not been achieved since the year 2012.

The impact of public infrastructure on economic growth has been a subject of discussion in literature since the contribution of Aschauer (1989) seminar work and the theoretical model of Barro (1990). Aschauer who found that core infrastructure had significant explanatory role in US productivity, argued that decrease in public investment may have been crucial in explaining the US economy's relatively poor economic performance between 1970s and 1980s. Theoretically, Barro's model introduced government expenditure as a public good in the production function with the effect of increasing the rate of return to private capital which in turn would stimulate economic growth. However, the source of financing such expenditures has been regarded as growth retarding due to disincentive effects associated with taxation (Musgrave \& Musgrave, 1989). But, Barro argues that the benefits derived from infrastructure investment may be offset by the negative impact of additional distortionary taxes to finance them. Mittnik and Neumann (2001) also maintained that government expenditure crowds out private investment due to borrowing. Nevertheless, Maingi (2010) criticized crowding out hypothesis by arguing that it neglects the importance of public sector services as inputs to the private sector.

Investing in infrastructure so as to boost economic growth and improve international competitiveness of a country is vital to both developed and developing countries. The economic successes of China, South Korea and Taiwan owe in part to massive infrastructure investment (Embassy of United States of America, 2012). Sahoo et al. (2010) points out that in 2006 infrastructure investment in China accounted 14\% of GDP and the country had massively developed infrastructure in nineties and as a result, China's economic growth increased from $7.5 \%$, in the period 1970 to 1999, to over 10\% per annum between 1999 to 2008. The World Bank estimates that developing countries need to invest 7 - 9\% of GDP to infrastructure in order to achieve broader economic growth and poverty reduction goals (Republic of Kenya 2006, United Nations Conference on Trade and Development, 2008). According to Kumo (2012) economic infrastructure investment in South Africa accounted 6.05\% and 7.64\% of GDP in 2008 and 2009 respectively compared to the period 1960 to 1993 when the investment was $6.68 \%$. In Kenya, government investment in infrastructure over the period 2000 to 2010 accounted about 3\% to 4\% of GDP (Poverty Reduction and Economic Management Unit Africa Region, 2011). Thus, infrastructure in the country is underinvested and this raises the question concerning the role of infrastructure in the achievement of sustainable economic growth in Kenya.

Kenya's pursuit for infrastructure investment started in earnest soon after the country gained political independence in 1963. Accordingly, the Sessional Paper Number 10 of 1965 asserts that the country developed transport, energy and other basic infrastructure with the aim of transforming the country into the market economy while laying the basis for a rapid acceleration of industrial growth. Notwithstanding, the rate of public investment in infrastructure began falling in the 1970s and has resulted in the deficiency and obsolescence of infrastructure in the country and mounting investment needs (Kimenyi, Mbaku \& Mwaniki, 2009). Due to inadequate supply of infrastructure in the country, the infrastructure inefficiencies that have resulted according to Wekesa (2015) include; congested roads, erratic power supply, long waiting lists for installation of telephone and power lines, shortages of clean and safe drinking water, overloaded disposal system and pollution, among others like declining 
life expectancy rates, high infant mortalities, overstretched facilities in schools and universities. As a result, the ERSWEC identified poor infrastructure as a major constraint to doing business in Kenya and it took infrastructure as an important prerequisite in creating and supporting a business environment capable of facilitating investment, growth and job creation (RoK, 2003). Further, the Sessional paper Number 10 of 2012 on Kenya Vision 2030 gives priority also to investment in infrastructure as the country aspires to provide cost effective and world class infrastructure facilities and services.

Following this, since the year 2003, the government has increased budgetary resource allocation to various infrastructure facilities. For instance, the development expenditure for infrastructure's development, rehabilitation and maintenance increased from Ksh 13.8 billion in 2000/03 to Kshs. 200.3 billion in 2014/15 (RoK, 2007, 2013). This funding improvement resulted to first, almost $1 \%$ that infrastructure contributed to Kenya's annual per capita GDP growth in the last decade as Africa Infrastructure Country Diagnostic [AICD] (2010) reports and secondly to Kenya's improvement in infrastructure ranking from 35th to 23th position in the year 2000 and 2010 respectively (Africa Development Bank, 2013). AfDB (2014) also recounts that Kenya channeled almost 27\% of its national budget over 5 years towards infrastructure. Despite this commitment, Republic of Kenya (2013) reports that Kenya needs sustained expenditures of almost $\$ 4$ billion per year over the next decade in order to address infrastructure deficit in the country. This illustrates the widening gap between demand for and supply of infrastructure and it raises doubts if infrastructure development is an enabler for sustainable economic growth in the Kenya.

In literature, positive and significant relationship has been obtained between economic infrastructure and economic growth. However, the impact of social infrastructure on growth process is not as clear-cut. For example, while Vukeya (2015) in South Africa found that social infrastructure has no role in economic growth, Kularatne (2006) in South Africa and Sahoo et al. (2010) in China found that social infrastructure has a positive and significant impact on growth. In Kenya, Mburu (2013) found that infrastructure investments have positive and significant relationship with economic growth. However, Mburu analyzed only the economic infrastructure without modeling the social infrastructure and used a small study period, which he admits posed serious drawbacks in drawing clear cut conclusion from the results. In view of the above, limited research explores infrastructure investment in Kenya and in addition, the existing literature is not in consensus on infrastructure - growth relationship It is against this background that this study sought to determine the effect of government infrastructure investment on economic growth in Kenya from 1990 to 2017.

\subsection{Objectives of the Study}

The main objective of the study was to determine the effect of government infrastructure investment on economic growth in Kenya

\subsubsection{Specific Objectives}

i. To determine the effect of economic infrastructure investment on economic growth in Kenya

ii. To analyze the effect of social infrastructure investment on economic growth in Kenya

\subsection{Literature Review}

This section reviews empirical and theoretical literature of public infrastructure investment and economic growth.

\subsection{Empirical Literature}

By employing Ordinary Least Squares (OLS), Aschauer (1989) determined whether public expenditure was productive in United States from 1949 to 1985. The study found that core infrastructure like highways, airports, mass transit, sewer, water systems had most explanatory power for the productivity in USA with elasticity of 0.24. However Tatom (1991), while re-estimating the regression of Aschauer by using variables in their first difference, found the elasticity of infrastructure as 0.14 . The high margin of the elasticities found by the aforesaid studies sparked the need to conduct a study on infrastructure investment and economic growth in Kenya.

While using Generalized Methods of Moment (GMM) and Autoregressive Distributed Lag model (ARDL), Sahoo et al. (2010) investigated the role of infrastructure development in promoting economic growth in China for the period 1975 - 2007. The findings of the study were that infrastructure development in China had a positive and significant contribution to Chinese economy than both public and private investment. Further, their study found unidirectional causality running from infrastructure development to output growth justifying huge investment of infrastructure development in China since nineties and bidirectional causality between GDP and public and private investment. Nevertheless, their study used GMM and ARDL estimation technique but this study used OLS to estimate the model.

While investigating significance of infrastructure investment on economic growth in Pakistan, Younis (2016) found that private investment and social infrastructure investment had positive and significant long-run impact on economic growth while economic infrastructure investment affected economic growth negatively in Pakistan. Ghani and Din (2006) also in Pakistan, explored the role of public investment on economic growth and they found that growth is largely driven by private investment and that there is no strong relationship that can be drawn 
between the effects of public investment and public consumption on economic growth. By using Cobb Douglas function estimation technique, Serdaroğlu (2016) determined the relationship between public infrastructure and economic growth in Turkey and found that total public infrastructure capital investments are significant booster of economic growth. In another study, Nedozi, Obasanmi and Ighata (2014) evaluated infrastructural development and economic growth and found that infrastructure is an integral part of Nigerian economic growth and that labour force in Nigeria decreases GDP by 0.96 units.

In a study to explore the impacts of economic and social infrastructure on economic growth in South Africa, Kularatne (2006) used Pesaran, Shin and Smith (PSS) ARDL and Vector Error Correction Model (VECM) while adapting Barro's (1990) model. The study created indices of economic infrastructure using roads and railway and an index of social infrastructure using schooling. The study findings indicate that both economic and social infrastructure has a positive and significant effect on economic growth and private investment is crowded in. Similarly, Vukeya (2015) while assessing the impact of government economic and social infrastructure investment on South African economic growth for the period 1983-2013 found that economic infrastructure investment is an important determinant of growth though social infrastructure investment and private investment have negative effect. Contrary to Kularatne findings, the causality patterns found in Vukeya's study suggest that growth tends to cause economic infrastructure investment thus supporting Wagner Law and neutral causality exists between growth and social infrastructure investment. Their studies had inconclusive findings between infrastructure investment and economic growth, therefore creating interest for a study based in Kenya to be conducted.

Mburu (2013) carried out a study on the relationship between government investment in infrastructure and economic growth in Kenya for the period 2005 to 2012. The study adopted a descriptive research design and established that infrastructure development in Kenya has a positive and significant effect on economic growth. In a similar study, Chingoiro and Mbulawa (2016) found that there was no cointegration between the infrastructure expenditure and economic growth since only short run relationships existed but not long run relationships. Chingoiro and Mbulawa also found that bidirectional causality exists between economic growth and infrastructure. In another study, Ndonga (2014) on government expenditure and economic growth in Kenya found that expenditures on infrastructure, health and defense have positive and significant impact on growth. Therefore, this study determined the effect of government infrastructure investment on economic growth in Kenya for the period 1990 to 2017 and compared the findings.

\subsection{Theoretical Literature}

This study was based on Barro's simple endogenous growth model.

\subsubsection{The Simple Model of Endogenous Growth}

Barro (1990) constructed this model and considered a broad concept of capital, encompassing both human and non-human capital. Human investment in the model includes education and training, as well as expenses for having and raising children. Non-human investments considered are physical or economic infrastructure investments such as highways and electricity. The theory assumes that constant returns to scale in the factors can be roughly accumulated and growth rise if both human and physical capitals are considered together. These two factors are possible complements in the production process and production may indicate diminishing returns for both types of capital should they be used separately. Importantly, the theory asserts that the economy has no transitional dynamics and is always in a position of steady state growth, where all quantities grow at an identical constant rate. But, this is contrary to neoclassical framework which argues that investment tends to impact growth on transitional period.

The theory further assumes a closed economy where the government does not own any capital nor produce any goods or services; it merely buys a flow of output from the private sector. These productive services that the government provides correspond with inputs the private sector needs. The role of public services is a direct input into private production. This production role creates opportunities for positive linkages between government investment and growth, implying that government investment plays a contributory role in the productivity of private investment. The Cobb-Douglas production function can be written as:

$$
y=A k^{1-\alpha} g^{\alpha} \quad 0<\alpha<1
$$

Where $y$ denotes output per worker, $A$ measures the level of technology, $k$ represents the representative producer's quantity of capital and $g$ is productive government expenditure per worker. These services are assumed to be non-rival and non-excludable, to support these assumptions. From the model, output is determined by parallel combinations of $k$ and $g$ in the production process of the economy. Production exhibits constant returns to scale in $k$ and $g$ together; however, it exhibits diminishing returns in $k$ and $g$ separately. Diminishing returns are a consequence of not increasing government inputs by an equivalent ratio as private inputs.

When government expenditure is financed by a flat-rate income tax, Barro (1990) argues that government runs a balanced budget since quantity of public services provided to each household-producer equates revenue from tax and aggregate expenditure, $\tau=g / y$. In addition, the theory argues expanding productive government expenditures relative to output raises the growth rate by raising the marginal product of capital. The theory 
concluded that there exists an optimal level of public-sector expenditure on productive services at which the rate of economic growth is optimized, beyond which the negative tax effect dominates the productivity effect and the rate of economic growth declines. However, it is difficult to estimate this optimal level in reality.

\subsection{Methodology}

This section reviews research design, data collection, model specification and analytical technique.

\subsection{Research Design}

Causal research design was used to establish the cause - effect relationship between government infrastructure investment and economic growth in Kenya.

\subsection{Data Collection}

Time series data was obtained from secondary sources which included Kenya National Bureau of Statistics economic surveys, statistical abstracts and World Development Indicators (WDI).

\subsection{The Model Specification}

The study adapted Barro (1990) theoretical framework and included labour as an additional input. The production function is given as:

$Y=\mathrm{A}(\mathrm{G}, \mathrm{K}, \mathrm{L}, \mathrm{e})$

Where Y refers to output, as a function of private capital, $\mathrm{K}$, public capital, G, which comprises government investment in economic and social infrastructure, L, labour force and e representing others factors influencing economic growth not included in the model.

The final empirical model to be predicted in logarithms was written as follows;

$\operatorname{LogGDPt}=\beta_{0}+\beta_{1} \log \mathrm{ECONii}_{t-\mathrm{i}}+\beta_{2} \log \mathrm{SOCii}_{\mathrm{t}-\mathrm{i}}+\beta_{3} \log \mathrm{PRI}_{\mathrm{t}-\mathrm{i}}+\beta_{4} \log \mathrm{L}_{\mathrm{t}-\mathrm{i}}+\mu_{\mathrm{t}}$

Where

Log GDP - Logarithm of gross domestic product

Log ECONii - Logarithm of economic infrastructure investment

Log SOCii - Logarithm of social infrastructure investment

Log L - Logarithm of labour force

Log PRI- Logarithm of private investment

Economic infrastructure investment (transport, ICT, energy and water and sanitation) was measured by real development expenditure while social infrastructure investment by education and health expenditures in real terms. Economic growth was measured using GDP growth rates whereas labor force and private investment were measured in annual \% growth and real gross fixed capital formation for private sector as a percentage of GDP respectively.

\subsection{Analytical Technique.}

Data was analyzed with the help of E-Views and Ox Metrics statistical softwares. To avoid spurious regression, time series property tests carried out were unit root, granger causality and cointegration. Ordinary Least Squares (OLS) technique was employed to estimate the relationship between government infrastructure investment and economic growth in Kenya. The overall significance of the model was tested using F-statistic at 5\% significance level. Further, the goodness of fit of the model was evaluated using coefficient of multiple determination R squared. The statistical significance of the coefficients was made using the $t$ - probability value at $5 \%$ significance level.

\subsection{Results and Discussions}

This section discusses the results of data analysis which include unit root test, granger causality test, cointegration and Error Correction Model (ECM).

\subsection{Stationarity test}

Time series data is said to be stationary if the mean, variance and covariance do not vary with time. Non- stationary variables results into spurious regression meaning there is presence of trend in the data series. The study variables were tested for stationarity using both Augmented Dickey-Fuller (ADF) and Phillips-Perron (PP) tests with the help of Pc Give Ox metrics and Eviews softwares respectively. The decision rule to accept the null hypothesis, indicating presence of unit root, would occur if ADF and PP statistics are greater than the critical value and Mc Kinnon critical value at 5\% level of significance. The variables were first tested in their level forms and if found non - stationary then first differencing was conducted. Table 1 shows the stationarity test results. 
Table 1: Stationarity Test Statistic on Data in Level Form and First Difference

\begin{tabular}{lllll}
\hline \hline Variables & Form & ADF Test & PP Test & Status \\
\hline LNGDP & Level & $-5.284^{* *}$ & -4.3376 & Stationary \\
LNECONii & Level & -1.713 & -0.4741 & Not Stationary \\
DLNECONii & $1^{\text {st }}$ Difference & $-4.637 * *$ & -5.1870 & Stationary \\
LNSOCii & Level & -2.640 & -1.6212 & Not Stationary \\
DLNSOCii & $1^{\text {st }}$ Difference & $-5.297 * *$ & -6.2072 & Stationary \\
LNPVK & Level & -2.151 & -1.4716 & Not Stationary \\
DLNPVK & $1^{\text {st }}$ Difference & $5.160^{* *}$ & -4.9369 & Stationary \\
LNL & Level & -1.841 & -3.6853 & Not Stationary/ \\
& & & & Stationary \\
DLNL & $1^{\text {st }}$ Difference & $-4.849^{* *}$ & -7.5379 & Stationary \\
\hline
\end{tabular}

ADF Critical level 5\% = -3.60; PP level Mc Kinnon Critical Value 5\% $=-2.9750$

The results shown in Table 1 indicate that LnGDP was stationary in level form since the computed ADF test and PP test was less than the critical value and Mc Kinnon critical value at 5\% significance level. LNECONii, LNSOCii, LNPVK were not stationary in level form but became stationary after the first difference in both ADF and PP tests. However, LnL was not stationary in ADF test but stationary in PP test and upon taking the first difference it became stationary.

\subsection{Granger Causality Test}

Granger causality test was performed to determine whether one time series was useful in forecasting another. The null hypothesis of non - causality was tested where the p-value was compared with the critical value at 5\% significance level. A p-value of less than 0.05 shows presence of causality between the variables while a p-value greater than 0.05 indicates absence of causality. The granger causality test was carried out with the aid of E-views software and the results are presented in Table 2.

Table 2: Granger Causality Test Results

\begin{tabular}{llll}
\hline \hline Null Hypothesis & Obs & F- Statistic & Probability \\
\hline LNECONII does not Granger Cause LNGDP & 26 & 4.26291 & 0.02794 \\
LNGDP does not Granger Cause LNECONII & 26 & 0.90475 & 0.41984 \\
LNSOCII does not Granger Cause LNGDP & 26 & 1.49276 & 0.24765 \\
LNGDP does not Granger Cause LNSOCII & 26 & 0.72105 & 0.49789 \\
LNPVK does not Granger Cause LNGDP & 26 & 1.40533 & 0.26742 \\
LNGDP does not Granger Cause LNPVK & 26 & 4.35736 & 0.02613 \\
LNL does not Granger Cause LNGDP & 26 & 0.15874 & 0.85424 \\
LNGDP does not Granger Cause LNL & 26 & 0.63318 & 0.54074 \\
\hline
\end{tabular}

From Table 2, unidirectional causality running from economic infrastructure investment to gross domestic product with a p-value of $0.02794(<0.05)$ was obtained. This implies that ECONii is required to be on the right hand side of the equation as an independent variable meaning that economic infrastructure investment granger causes economic growth in Kenya. This finding supports Keynesian hypothesis that states that an increase in government expenditure causes GDP to increase. Interestingly, GDP was found to have unidirectional causal impact on private investment thus supporting Wagner's law. However, social infrastructure investment, labour force and GDP have neutral causality since their $p$ - value is greator than 0.05 meaning they are independent of each other.

\subsection{Cointegration Test}

Cointegration test was conducted to establish whether there was long run relationship between the dependent and independent variables. Cointegration was tested using Johansen approach and the results are presented in Table 3. Table 3: Results of Cointegration Test

\begin{tabular}{lllll}
\hline \hline Eigenvalue & $\begin{array}{l}\text { Likelihood } \\
\text { Ratio }\end{array}$ & $\begin{array}{l}\text { 5 Percent } \\
\text { Critical Value }\end{array}$ & $\begin{array}{l}\text { 1 Percent } \\
\text { Critical Value }\end{array}$ & $\begin{array}{l}\text { Hypothesized } \\
\text { No. of CE(s) }\end{array}$ \\
\hline 0.772881 & 108.2169 & 87.31 & 96.58 & None ** \\
0.619640 & 69.67758 & 62.99 & 70.05 & At most * $^{*}$ \\
0.604391 & 44.54500 & 42.44 & 48.45 & At most $2 *$ \\
0.422788 & 20.43445 & 25.32 & 30.45 & At most 3 \\
0.210531 & 6.146263 & 12.25 & 16.26 & At most 4 \\
\hline
\end{tabular}

$*(* *)$ denotes rejection of the hypothesis at $5 \%(1 \%)$ significance level.

From Table 3 above, Likelihood Ratio (L.R.) test indicates 3 cointegrating equation (s) at 5\% significance level. This means that long run relationship exists between dependent variable (economic growth) and independent variables (economic and social infrastructure investments, labour force and private investment). Therefore, the 
evidence of cointegration rules out the possibility of spurious correlation (Maingi, 2010).

\subsection{Error Correction Model}

Upender (2003) asserts that an error correction modeling helps to examine the presence of equilibrium or disequilibrium between short run dynamics and long run equilibrium. The speed of adjustment given by Error Correction Term (ECT) should bear a negative sign thus indicating presence of equilibrium relationship. The ECM results are shown in Table 4.

Table 4: Error Correction Model Results

\begin{tabular}{lcccc}
\hline \hline & Coefficient & Standard Error & t-value & p-value \\
\hline Constant & 0.005777 & 0.08206 & 0.0704 & 0.9449 \\
DLNECONii & -0.03865 & 0.1094 & -0.353 & 0.7291 \\
DLNECONii_1 & 0.8326 & 0.1200 & 6.94 & 0.0000 \\
DLNSOCii & -0.1615 & 0.08694 & -1.86 & 0.0843 \\
DLNSOCii_1 & -0.01353 & 0.08780 & -0.154 & 0.8798 \\
DLNPVK & 0.5882 & 0.08549 & 6.88 & 0.0000 \\
DLNPVK_1 & -0.7613 & 0.1103 & -6.90 & 0.0000 \\
DLNL & -0.8906 & 0.1579 & -5.64 & 0.0001 \\
DLNL_1 & -0.3603 & 0.09945 & -3.62 & 0.0028 \\
ECT & 0.9642 & 0.04429 & 21.8 & 0.0000 \\
ECT_1 & -1.1532 & 0.08915 & -12.9 & 0.0000 \\
\hline
\end{tabular}

$\mathrm{R}^{2}=0.987493 \quad \mathrm{~F}(11,14)=100.5[0.000]^{* *} \quad \mathrm{DW}=1.88$

Table 4 presents regression results for ECM which can be restated as follows;

$\mathrm{GDP}=0.005777+0.8326 \mathrm{ECONii}-0.01353 \mathrm{SOCii}-0.7613 \mathrm{PVK}-0.3603 \mathrm{~L}-1.1532 \mathrm{ECT}$

From the results in Table 4, the model had a constant of 0.005777 . This shows that economic growth would grow by $0.58 \%$ independent of the exogenous variables included in the model. The measure of goodness of fit given by R squared was 0.9874 implying that $98.74 \%$ of the variations of the economic growth were explained by government investment in economic and social infrastructure, private investment and labour force. The remaining $1.26 \%$ is attributed to variables not included in the model.

The F-statistic was 100.5 with a p-value of 0.000 which is less than 0.05 signifying that the overall model is significant in predicting the relationship between dependent variable and independent variables. The DW statistic was 1.88 and greater than $\mathrm{R}^{2}$ showing absence of spurious regression in the model. The lagged ECM term was negative as expected and statistically significant. The coefficient of ECT indicates a speed of adjustment of $115.32 \%$ from actual growth in the previous year to equilibrium rate of economic growth. This means that there exists short run and long-run relationship between economic growth and government infrastructure investment, private investment and labour force.

Economic infrastructure investment was found to have a positive and significant effect on economic growth with a coefficient of 0.8326 and a p-value of $0.0000<0.05$. This denotes that a unit increase in economic infrastructure investment (transport, energy, ICT and water and sanitation) increases economic growth by $83.26 \%$ when other factors are held constant. Since the p-value $0.0000<0.05$, the null hypothesis was rejected and the conclusion arrived at was that economic infrastructure investment has a statistically significant effect on economic growth in Kenya. This finding implies that increased government investment in economic infrastructure increases economic growth in Kenya. The study finding agrees with the empirical works of Aschauer (1989), Tatom (1991), Sahoo et al. (2010), Kularatne (2006), Vukeya (2015), Mburu (2013) and Ndonga (2014). However, the study findings differs with Younis (2016) who found that economic infrastructure investment has a negative effect on economic growth in Pakistan.

Contrary to the expectations, social infrastructure investment had negative and insignificant effect on economic growth with a coefficient of -0.01353 and a p-value of $0.8798>0.05$. This means that a unit increase in social infrastructure investment decreases economic growth in Kenya by $1.3 \%$ other factors remaining constant. Since the p-value is greator than 0.05 , the study failed to reject the null hypothesis and the conclusion arrived at was that social infrastructure investment is not a significant determinant of economic growth in Kenya. This could be due to the fact that social infrastructure investment (education and health facilities) in the country has been neglected and underdeveloped over the years as evidenced by overcrowded education and health facilities majority being in poor condition. All the same, the results concurs with Vukeya (2015), but differs with Younis (2016) and Kularatne (2006).

Private investment was found to have a negative and significant effect on economic growth with a coefficient of -0.7613 and a $\mathrm{p}$-value $0.0000<0.05$. This denotes that a unit increase in private investment decreases economic growth by $76.13 \%$ while holding other factors constant. Granger causality test justifies this finding since 
unidirectional causality running from GDP to private investment was obtained implying that economic growth in Kenya drives private investment and not otherwise. Besides, private investment had a $p-$ value of $0.0000<0.05$, therefore the null hypothesis was rejected at 5\% significance level and the conclusion arrived at was that private investment has a statistically significant effect on economic growth in Kenya. This finding disagrees with Barro (1990) model that takes private investment as a complement to public infrastructure investment. Empirically this finding differs with the findings of Sahoo et al. (2010), Ghani and Din (2006), Kularatne (2006), and Younis (2016) but concurs with Vukeya (2015) who found that private investment has a negative effect on economic growth in South Africa.

Labour force was found to have a negative but significant effect on economic growth with a coefficient of 0.3603 and a $p$-value of $0.0028<0.05$. This denotes that a unit increase in labour force will decrease economic growth by $36.03 \%$ holding other factors constant. Labour force was statistically significant since the p-value was $0.0028<0.05$ and this led to the rejection of null hypothesis at $5 \%$ significance level. This result agrees with Nedozi et al. (2014) who found that labour force in Nigeria decreases GDP by 0.96 units. The negative effect that labour force has on economic growth implies underutilization or unemployment of the work force in the country and this lowers the efficiency of labour in the production of output.

\subsection{Conclusions and Recommendations}

This sections looks at the conclusions and recommendations.

\subsection{Conclusions}

The study determined the effect of government infrastructure investment on economic growth from the year 1990 to 2017. From regression analysis economic infrastructure investment was found to have positive and significant effect on economic growth in Kenya. As a result, the study concluded that government investment in economic infrastructure promotes economic growth in Kenya. On the other hand, social infrastructure was found to have negative and insignificant effect on economic growth in the country and therefore the study concluded that social infrastructure investment has a negative and statistically insignificant effect on economic growth in Kenya. Both private investment and labour force had negative and significant effect on economic growth in Kenya. Therefore, the conclusion made was that private investment in the country decreases economic growth and this was as a result of crowding out effect arising from government expenditure on infrastructure. Moreover, the study also concluded that labour force decreases economic growth in Kenya due to high unemployment rates in the country.

\subsection{Recommendations}

The study recommends the following:

i. There is more potential for infrastructure (economic and social) to be an enabler for the envisioned $10 \%$ economic growth rate in Kenya. Therefore, the government needs to increase infrastructure funding to 7-9\% of GDP as recommended by World Bank. This will lead to increased productivity due to increased physical and human capital thus high economic growth. Additionally, misappropriation of public funds allocated to infrastructure investment needs to be curbed by sealing any loopholes identified and carrying out regular monitoring and evaluation on their use.

ii. The government should ensure that its infrastructure spending is complementary to the private sector investment as this will raise marginal capital of private sector and also increase investment in form of direct productive activities as private investors will be motivated to invest thus raising economic growth.

iii. The study established that labour force had negative effect on economic growth and this could be attributed to high unemployment rate in the country. Therefore, the government should promote conducive environment for private investment since more job opportunities would be created thereby absorbing the underutilized or unemployed labour force and as a result reduce the unemployment levels in the country.

\section{References}

Africa Infrastructure Country Diagnostic (2010). Kenya's Infrastructure: A Continental Perspective. Washington, DC: World Bank.

African Development Bank Group (2014). Kenya: Country Strategy Paper 2014-2018. East Africa Resource Center.

African Development Bank. (2013). The Africa Infrastructure Development Index (AIDI): African Development Bank Group.

Aschauer, D. (1989). Is Government Spending Productive? Journal of Monetary Economics, 23, 177-200.

Barro, R. (1990). Government Spending in a Simple Model of Endogenous Growth. The Journal of Political Economy, 98 (5), 103 - 125.

Chingoiro, S., \& Mbulawa, S. (2016). Economic Growth and Infrastructure Expenditure in Kenya Granger Causality Approach. International Journal of Social Science Studies, 4(9). 
Embassy of the USA (2012). Better Infrastructure Brings Economic Growth. United States Department of State Bureau of International Information Programs.

Fedderke, J., \& Garlick, R. (2008). Infrastructure Development and Economic Growth in South Africa: A Review of the Accumulated Evidence. Economic Research of Southern Africa, Policy Paper 12.

Fox, W. F., \& Porca, S. (2001). Investing in Rural Infrastructure. International Regional Science Review, 24(1), $103-133$.

Fox, W. F., \& Smith, T. R. (1990). Public Infrastructure Policy and Economic Development. Economic Review.

Gakuo, E. W. (2015). The Relationship between Government Investment in Energy Infrastructure and Economic Growth in Kenya. Unpublished Master's Thesis, University of Nairobi, Nairobi, Kenya.

Ghani, E., \& Din, M. (2006). The Impact of Public Investment on Economic Growth in Pakistan. The Pakistan Development Review, 45 (1), 87-98.

Gramlich, E. (1994). Infrastructure Investment: A Review Essay. Journal of Economic Literature, 32 (3), 1176 1196.

Hansen, N. M. (1965). Unbalanced Growth and Regional Development. Western Economic Journal, 4, 3-14.

Hirschman, A. (1958). The Strategy of Economic Development. New Haven: Yale University Press.

Kimenyi, J. M., Mbaku, \& Mwaniki, N. (2009). Restarting and Sustaining Economic Growth and Development in Africa: the Case of Kenya. Ashgate.

Kularatne, C. (2006). Social and Economic Infrastructure Impacts on Economic Growth in South Africa. Presented at the University of Cape Town School of Economics Staff Seminar Series, South Africa.

Kumo, W. (2012). Infrastructure Investment and Economic Growth in South Africa: A Granger Causality Analysis. African Development Bank Group, Working paper No. 160.

Maingi, J. N. (2010). The Impact of Government Expenditure on Economic Growth in Kenya: 19632008. Unpublished PHD Thesis, Kenyatta University, Nairobi, Kenya.

Mburu, J. M. (2013). Relationship between Government Investment in Infrastructure and Economic Growth in Kenya. Unpublished Master's Thesis, University of Nairobi, Nairobi, Kenya.

Mittnik, S., \& Neumann, T. (2001). Dynamic Effects of Public Investment: Vector Autoregressive Evidence from Six Industrialized Countries. Empirical Economics, 26(2), 429- 446.

Mudida, R. (2010). Modern Economics. ( $2^{\text {nd }}$ Ed.). Nairobi: Focus Publishers Ltd.

Mugambi, A. M. (2016). Roads Infrastructure Investment and Economic Growth in Kenya: The Role of Private and Public Sectors. Unpublished Master's Thesis, University of Nairobi, Nairobi, Kenya.

Musgrave, R. A., \& Musgrave, P.B. (1989). The Theory of Public Finance. New York: McGraw-Hill.

Nedozi, F.O., Obasanmi, J.O., \& Ighata, J. A. (2014). Infrastructural Development and Economic Growth in Nigeria: Using Simultaneous Equation. Journal of Economics, 5(3), 325-332.

Perkins, P. (2003). The Role of Economic Infrastructure in Economic Growth: Building Experience. Unpublished Master's Thesis, University of Witwatersrand, South Africa.

Poverty Reduction \& Economic Management Unit Africa Region (2011). A Bumpy Ride to Prosperity. Infrastructure for Shared Growth in Kenya. Regional Science Review, 24(1), 103-133.

Republic of Kenya (1965). Sessional Paper Number 10 of 1965 on African Socialism and its Application to Planning in Kenya. Nairobi: Government Printers.

Republic of Kenya (2003). Economic Recovery Strategy for Wealth and Employment Creation (2003-2007). Nairobi: Government Press.

Republic of Kenya (2006): Ministry of Roads and Public Works. Sessional Paper of 2006 on the Development and Management of the Roads Sub-Sector for Sustainable Economic Growth. Nairobi.

Republic of Kenya (2007). Medium Term Expenditure Framework: Energy, Physical Infrastructure and ICT. Retrieved on 19th April 2018 from: http://www. treasury.go.ke/Resources.html.

Republic of Kenya (2010). Medium Term Expenditure Framework: Energy, Physical Infrastructure and ICT. Retrieved on 19th April 2018 from:http://www. treasury.go.ke/Resources.html.

Republic of Kenya (2013). Medium Term Expenditure Framework: Energy, Physical Infrastructure and ICT. Retrieved on 19th April 2018 from http://www. treasury.go.ke/Resources.html.

Republic of Kenya (2013). Medium Term Plan, 2013-2017 of Vision 2030. Nairobi: Government Press.

Republic of Kenya (2018): The National Treasury and Planning. Comprehensive Public Expenditure Review. From Evidence to Policy.

Romp, W., \& De Haan, J. (2007). Public Capital and Economic Growth: A Critical Survey, 8 (1), 6 - 52.

Rostow, W. W. (1960). The Economics of Take-off into Self-Sustained Growth. New York: St. Martin's press.

Sahoo, P., Dash, R. K., \& Nataraj, G. (2010). Infrastructure Development and Economic Growth in China. IDE Discussion Paper No. 261, 1-16.

Serdaroğlu, T. (2016). The relationship between public infrastructure and economic growth in Turkey. Ministry of Development, General Directorate of Economic Modelling and Strategic Research. Ankara.

Smith, A. (1776). An Inquiry into the Nature and Causes of the Wealth of Nations. 
Tatom, J. A. (1991). Public Capital and Private Sector Performance. Federal Reserve Bank of St. Louis Review, $73,3-15$.

UNCTAD (2008). World Investment Report 2008: Transnational Corporations and the Infrastructure Challenge: Overview. New York and Geneva: United Nations.

UN-HABITAT (2011). Infrastructure for Economic Development and Poverty Reduction in Africa. Nairobi, Kenya.

Upender, M. (2003). Applied Econometrics ( $3^{\text {rd }}$ Ed.).Vrinda Publications (P) Ltd: Delhi.

Vukeya, V. (2015). The impact of Infrastructure Investment on Economic Growth in South Africa. Unpublished Master's Thesis, University of Zululand.

Wekesa, C. T. (2015). The Effects of Infrastructure on Foreign Direct Investment in Kenya for the Period 1970 to 2013. Unpublished Master's Thesis, Kenyatta University, Nairobi, Kenya.

Younis, F. (2016). Significance of Infrastructure Investment on Economic Growth. Munich Personal RePEc Archive (MPRA), 72659. 